\title{
The comparison of the scope of the content and classification methods on topographical maps of Polish territory annexed by Russia issued at the turn of 19th and 20th century
}

\begin{abstract}
The aim of the article was a comparison of the content's scope, classification and presentation methods on topographical maps issued at the turn of 19th and 20th century covering the territory of former Russian partition. Three of such maps were chosen for the analysis, namely: Russian (scale 1:84,000), Austrian (scale 1:75,000) and German (scale 1:100,000). As a starting point of the study served an attempt at reconstruction of map legends, as, a coherent symbology key (i.e. map legend) can be found neither for Russian nor German map. It was conducted by employing the symbology keys prepared in the Interwar Period, as for the Russian map there was no legend enclosed, while in the case of German the legend enclosed featured only the road network. Apart from the legends, an analysis of the map sheets covering four areas was conducted. Those areas were, as follow: Brest, Dęblin, Pinsk and Pultusk vicinites. The next stage was to elaborate a legend comparison with summary in the form of a table for particular thematic layers: settlement and built-up area, transport network, sacral buildings facilities and other buildings, land cover, hydrography, relief, and borders. An assumption was made that despite the apparent similarity of the scales $(1: 75,000$, $1: 84,000,1: 100,000)$ and source materials the maps analysed are distinct in terms of presentation of the geohistorical landscape. The settlements on the Russian map were illustrated in a schematic manner, while the other maps approached the subject more meticulously. The discrepancies involve also such areas as: road network, land cover, and waters, which were categorised along different sets of criterion. It happened that some categories present on the Russian map were absent from the Austrian and German. It involved such objects as: fascine roads, wooden churches or radiostations. Those differences stem from not only the "military mode" of elaboration of the German and Austrian map, but also conscious interference in the scope of content and classification methods.
\end{abstract}

Keywords: topography, topographic map, archival map, cartographic semiotics, Russian partition

\section{Introduction}

The old maps, also known as archival maps, are currently used as a source of data in geographical and historical research. In the course of last ten, twenty years we can observe not only a conspicuous trend connected with growing interest in the spatial humanities and the renaissance of historical geography, but also an increasingly widespread access to GIS tools, which facilitate data gathering, processing and visualization (I.N. Gregory, R.G. Healey 2007). Only in the last few years two publications focusing solely on the archival maps have been published, namely: a volume of "Works of Culture Landscape Commission" entitled:
Cartographical Sources in Cultural Landscape Research (Polish: Źrodła kartograficzne w badaniach krajobrazu kulturowego) (J. Plit, J. Nita 2012) and volume of "The Library of Polish Cartographical Review" - Old maps as historical sources (Polish: Dawne mapy jako źródła historyczne) (B. Konopska et al. 2012). Moreover, a number of articles in "Polish Cartographical Review" have been published (K. Nieścioruk 2007; B. Szady 2008; A. Sobala 2012; K. Lange 2013; T. Panecki 2014b; J. Kuna 2014). It does not necessarily mean that prior to that the old maps were not a subject of interest for the researchers, what can be supported by works by W. Grygorenko (1981) and S. Pietkiewicz (1995) which address the problem of map's mathematical accuracy. 
Despite the great interest among the researchers the problem of methodically adequate employment of archival topographical maps in the age of GIS tools still remains open. What is particularly interesting is the analysis of the scope of content and its classification in the context of maps used in the further research. Those two variables strongly affect the extent of potential analysis and should be addressed in greater detail. It was done, among many others, by J. Kuna (2014) who analysed in his work the changes of the graphic design and the meaning of particular symbols on the topographical maps at the scale 1:100,000 published in the 1920s. The issue of content variability and content presentation was also addressed by the author of the article while researching the works concerning the common symbol classification for archival topographic maps (T. Panecki 2014a).

The aim of the article is to pursue this research on the example of three particular partition topographic maps dating back to the turn of 19th and 20th century and covering the area of former Russian partition. The choice was not circumstantial as it was based on the premise that the Russian map $(1: 84,000)$ is an effect of an original topographical survey while Austrian $(1: 75,000)$ and German $(1: 100,0000)$ were elaborated on the basis of external materials (including the map at the scale $1: 84,000$ ). The similar scales and time of elaboration may suggest that there are similarities in their depiction of geographical reality as well. We should also bear in mind that the maps were elaborated by the Central Powers (i.e. Austria and Germany) in "military mode" right before the I World War and were soon supposed to be used at the Eastern front. The factor directly influencing the extent of the content and graphic design were short time devoted to the maps' elaboration and their purpose - field maps. Thus, what seems interesting is the analysis of the maps against the differences in the scope and methods of presentation of the content as well as an answer to the question of the extent of those differences between Russian, German and Austrian maps.

The scope of the content is in the following article understood as the total number of content categories in particular thematic layers (settlement and built-up areas, transport network, sacral buildings facilities and other build- ings, land use, hydrography relief, and borders. While "the methods of content presentation" represent the approach to categories elaboration and ordering within each thematic layer, e.g. the distinction of towns according to their size or administrative function, the division of roads according to their quality, function, width or classification of forests depending on the type of trees found there (deciduous, coniferous, mixed).

We can risk a statement, that despite the similarity of the scale and (to some extent) source materials, the analysed maps depict the geohistorical landscape in different manner, what can reflect in the methods of content presentation.

This leads to a number of questions including that of a degree of difference in the scope of the content and presentation as well as the reasons laying in their foundations. Do they only concern the map legend or do they also affect the graphic elaboration of the map (generalisation, number of presented categories, cartographic drawing manners)? Do those differences refer to the cultural landscape or natural one as well? And finally, can we detect any regularities in those differences?

The comparison of the scope of the topographical content and presentation methods was based primarily on the legend analysis. What was also crucial was to identify and analyse the area that was present on all maps, and that is the major reason for choosing map sheets covering the areas of Brest, Dęblin, Pinsk and Pułtusk vicinities as a basis.

\section{The materials}

As a basis for further analysis three maps from the turn of 19th and 20th century were chosen, namely: Russian at the scale 1:84,000 and two maps by Central Powers - Austrian $(1: 75,000)$ and German $(1: 100,000)$ (Fig. 2). The maps were acquired from the internet service "WIG Map Archive" (Polish: "Archiwum Map WIG") (Archiwum Map Wojskowego Instytutu Geograficznego 2015), as well as geoportal "Maps with a past" (Polish: "Mapy z przeszłością") (Cartomatic 2015).

Новая Топографическая Карта Западной России, 1:84,000, (,Two-verst”). The map was an effect of topographic survey run in 
Russia in 1880 . The survey was conducted at the scale $1: 21,000$ ) (half-verst) however since 1908 , in order to accelerate the works the scale was decreased twice and the original accuracy was maintained only for the towns and crucial objects. Meanwhile, in Congress Poland even though the works were conducted already in yeas 1860-1869, the changes in the cultural and political landscape resulted in the necessity to repeat the survey in the 1880 s. The effect was a map issued in 1883 in two-coloured version - black for the terrain situation and brown for contour lines. It was in Müffling projection and was $15^{\prime}$ wide and $27^{\prime}$ long (B. Krassowski 1973). Four sheets were chosen for the further analysis: „XXV-11” from 1908 (Dęblin), „XXI-19” from 1915 (Pułtusk), „XXIII-20” from 1915 (Pinsk), and „XXIII-15” from 1915 (Brest).

Spezialkarte der Österreichisch-Ungarischen Monarchie, 1:75,000, (,Spezialkarte”). The Third Military Survey by Austro-Hungarian Empire in 1873-1879 was at the foundation of the detailed map the scale 1:25 000 (Militär Aufnahmssektion) issued in one colour. On its basis so called "special map" (i.e. "accurate") was elaborated, which was in a scale 1:75,000 (Spezialkarte der Österreichisch-Ungarischen Monarchie), and which first issue was a result of works of Austrian Military Geographical Institute in the years 1873-1889. There were 690 sheets printed, which covered not only Austro-Hungary but also the area of Congress Poland (Russian partition) in the North and Polesie in the East. The projection used was the Polyhydric projection with zero meridian on Ferro Island ("Austrian Ferro"). The sheets were $15^{\prime}$ wide and $30^{\prime}$ long. Originally the map was black and white, though since 1912 some sheets were printed in four colour (F.P. Faluszczak 2011).

While on the area of former Austria-Hungary the source of the information constituted the topographical survey, for the former "Western Russia" the foundation was inconsistent and constituted mainly of Russian maps at the scales such as $1: 42,000$ and $1: 126,000$. Sometimes even the German map sheets at the scale 1:100,000 were reprinted (J. Lewakowski 1921). The sheets used in the analysis were as follows: „Zone: B, Kol. XXVI-Iwangorod" from the year 1914 (Dęblin), „2966” from the year 1916 (Pułtusk), „Zone: D, Kol. XXXIV” from 1914 (Pinsk), „Zone: D, Kol. XXIX; Brest-Litowsk” from 1911 (Brest).
Karte des Westlichen Russlands, 1:100,000, („KdWR”). The German preparations to the military conflict in Europe at the turn of 20th century required the maps of the areas East of the Reich. Because of that, in the period of 1914-1916 maps called Karte des Westlischen Russlands at the scale 1:100,000 were elaborated and issued. As a source served the Russian maps at the scale 1:84,000, the outdated, even in that time, Reymann map at the scale 1:200,000 (enlarging it), and the Austrian Spezialkarte 1:75,000.

The variety of sources resulted in inconsistencies in map design, e.g. in terms of relief presentation, which was of highest quality on the sheets based on Russian maps (contour lines) and much worse on those based on Reymann map (hachures). The names on the maps posed some problems as well, as they were transcribed from Cyrillic script. The size of the maps sheet (15' wide, and $30^{\prime}$ long) was the same as the original German map Karte des Deutschen Reiches at the scale 1:100,000. 300 sheets of $K d W R$ were issued (B. Krassowski 1973; A. Konias 2010). The analysis was based on following map sheets: „K35 Iwangorod” from 1915 (Dęblin), „H31 Pultusk” from 1915 (Pultusk), „S33 Pinsk” from 1915 (Pinsk) and „N33 Bresst-Litowssk” from 1914 (Brest).

\section{The comparison of the scope of content and classification methods on topographic maps}

A key element of the analysis was the symbol keys acquisition. In the case of archival maps, especially those issued in series through many years (including the supplements and updates) we can observe an array of inconsistencies in scope of content and classification methods between the map legend and the map itself. It may happen, that a symbol present on the map is included in the legend in a changed form, what prevents its full identification (D. Lorek 2012). It is a result of the changes in methods of content presentation, and consequently whenever it is only possible the information on the symbol designates should be extracted from the legend attached to the map sheet. This allows for the conclusion that the map content and the legend are consistent (T. Panecki 2014a). 
The major problem, however, was the acquisition of the symbology for the Russian maps. There was not even one sheet of two-verst map with a map legend attached. What is more, in all the collection of the map there is no sheet with symbol key included. Thus, in order to reconstruct the legend the works of the Military Geographical Institute (Polish: Wojskowy Instytut Geograficzny, WIG) along with elaborated by them symbol keys for 19th century maps covering Polish lands were employed (J. Lewakowski 1920; WIG 1925; S. Gąsiewicz 1930). It is difficult to precisely evaluate the accuracy of the reconstruction in reference to the original map content. However, they were elaborated for further WIG works, thus their credibility can be assessed as relatively high.

Even though the symbology key dating back to year 1925 presents a wider array of content than other, inconsistences and conflicts between classification methods are rather slight or negligible(e.g. "post route" in the set from 1925 represents "post road" in Gąsiewicz and Lewakowski's one). For the purpose of the analysis the Gąsiewicz and Lewakowski's symbol overview was supplemented with use of the one from 1925.

In the case of Austrian Spezialkarte there was an absence of map legend connected with particular map sheet, thus, leading to necessary use of general symbology key as a source of information. The general legend was attached to the series of maps including the one in question, therefore, being coherent with it. According to H. Libinski (1912) there was a number of such keys dating from: 1875, 1882, 1888, 1894 and

Tab. 1. Settlement and built-up area

\begin{tabular}{|c|c|c|}
\hline $1: 84,000$ & $1: 75,000$ & $1: 100,000$ \\
\hline \multicolumn{3}{|c|}{ Type and size of settlement } \\
\hline \multirow{5}{*}{ Cities } & Cities larger than 100,000 inh. & Cities larger than 100,000 inh. \\
\hline & Cities $50,000-100,000$ inh. & Cities $30,000-100,000$ inh. \\
\hline & $\begin{array}{l}\text { Cities, Markes places, Towns } \\
10,000-50,000 \text { inh. }\end{array}$ & Cities $5,000-30,000$ inh. \\
\hline & $\begin{array}{l}\text { Cities, Markes places, Towns } \\
2,000-10,000 \text { inh. }\end{array}$ & \multirow{2}{*}{ Cities lower than 5,000 inh. } \\
\hline & $\begin{array}{l}\text { Cities, Markes places, Towns } \\
\text { lower than. } 2,000 \text { inh. }\end{array}$ & \\
\hline \multirow{6}{*}{ Villages } & \multirow{6}{*}{ Villages } & Villages larger than 1,000 inh. \\
\hline & & Villages $400-1,000$ inh. \\
\hline & & Villages lower than 400 inh. \\
\hline & & Villages larger than 400 inh. \\
\hline & & Villages $100-4,000$ inh. \\
\hline & & Villages $20-100 \mathrm{inh}$. \\
\hline \multicolumn{3}{|c|}{ Built-up area } \\
\hline Built-up area & Built-up area & Built-up area \\
\hline Single buildings & \multirow[b]{2}{*}{ Single buildings } & \multirow[b]{2}{*}{ Single buildings } \\
\hline Khutor & & \\
\hline Farm & Outbuilding & \\
\hline \multirow[t]{2}{*}{ Demesne } & Mountain farm & \\
\hline & $\begin{array}{l}\text { Mountain farm similar to settle- } \\
\text { ment }\end{array}$ & \\
\hline
\end{tabular}


1904. J. Lewakowski (1920) and S. Gąsiewicz (1930), in turn, distinguish only between "old" and "new" systems of content classification, not mentioning any dates. In the case of WIG (1925) set of symbols only one version was listed.

The differences between the symbol classification were minor and concern mainly the road network. It is strongly connected with the map legend which is attached to the map sheet "Zone 1, Kol. IX" and refers to the symbol key dating back to 1904 , but it also enumerates separately the map elements from the years 1875, 1882 (collectively), 1888, and 1894, some of which were different from one another. What may catch our attention is the scope of the map content resulting, among other reasons, not only from its larger scale but also its geographical coverage. Spezialkarte covers a vast area from Bergamo in the West to Kamieniec Podolski in the East and ranges from Białystok in the North and Sofia in the South, thus the scope of the content necessarily had to inclu- de the nature of many different landscapes.

The German map legend can be found on the map sheet, however, it is relatively scarce and - except for the graphic scale in four versions - it only included the details of road and railway network. The remaining map content had to be reconstructed with use of symbol keys by WIG, with premise that each and every symbol present on them could appear on the map, thus the symbol key was treated as total collection of possible symbols (as long as there were no repetitions). The classification of settlement types is expressed with the size of labels used on the map and it is present only in S. Gąsiewcz (1930) symbol set. It is referred to as "types of writing on German maps", and consequently a statement can be risked, that they refer not only to KdWR, but also to Karte des Deutsches Reiches and Messtischblat.

The scope of all maps' content was divided into seven thematic layers: settlement and built-up area, transport network, sacral buildings facilities and other buildings, land use,

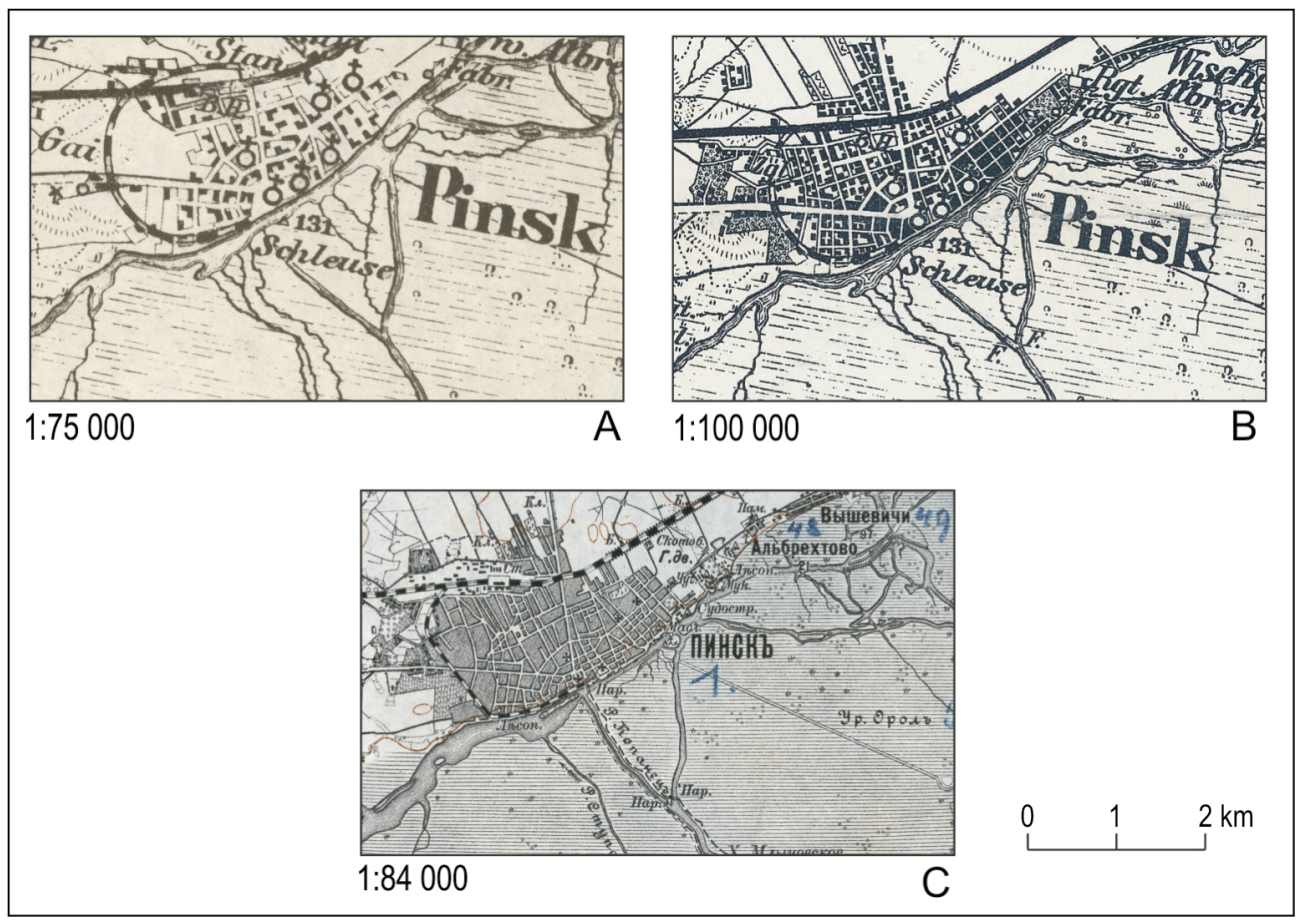

Fig. 1. Differences in built-up area depiction in Pinsk vicinities: A - Spezialkarte der Österreichisch-Ungarischen Monarchie, 1:75,000, „Zone: D, Kol. XXXIV”, 1914; B - Karte des Westlichen Russlands, 1:100,000, „S33“, 1915; C - Новая Топографическая Карта Западной России, 1:84,000, „XXIII-20”, 1915 


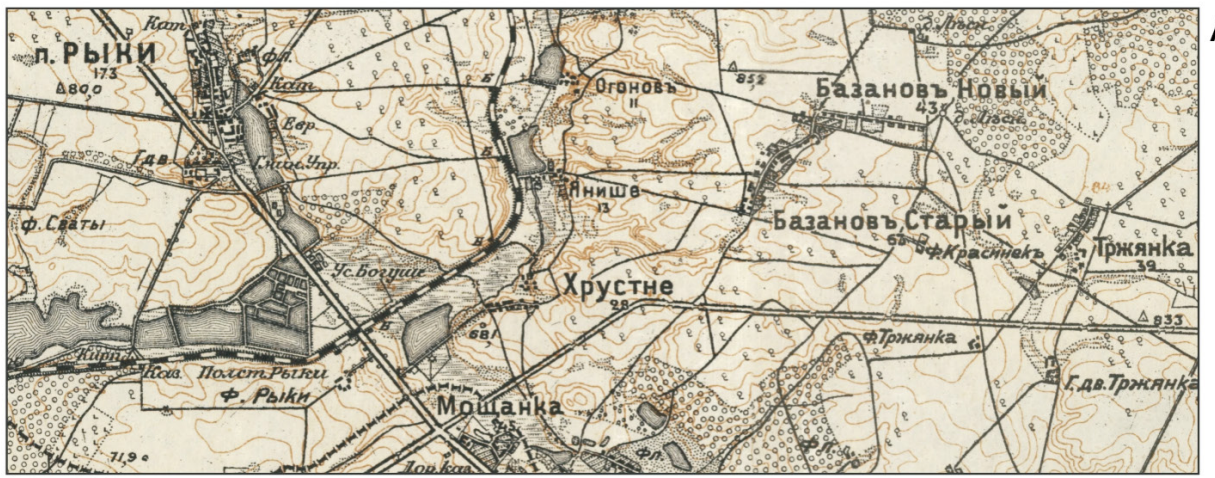

$1: 84000$

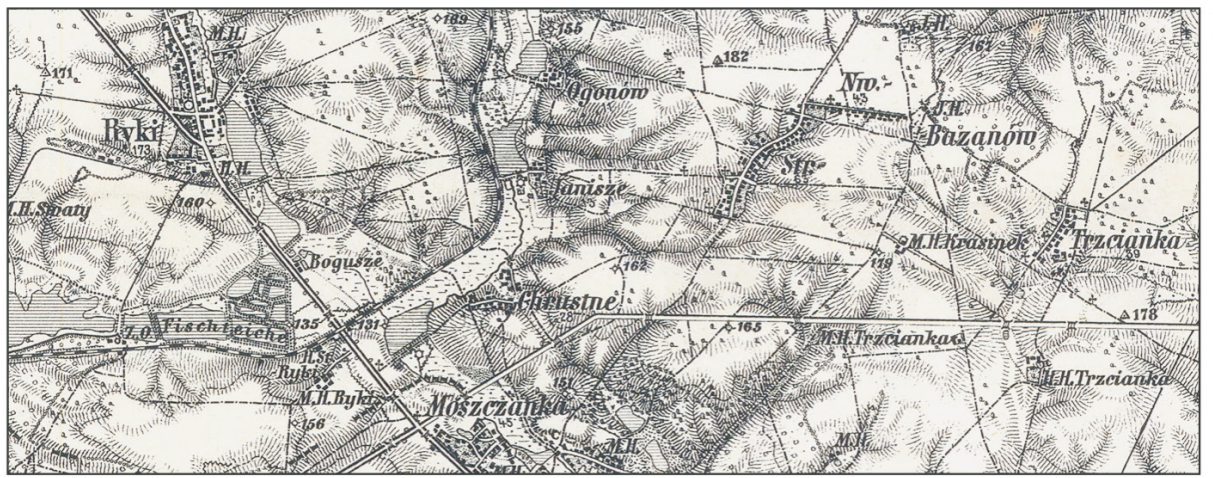

$1: 75000$

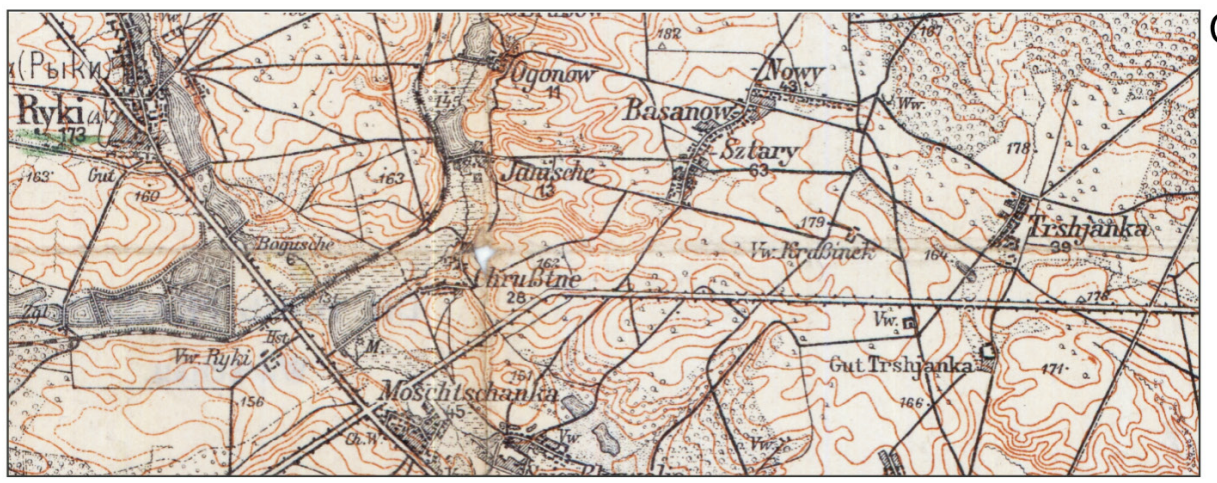

$1: 100000$

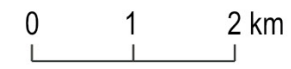

Fig. 2. Vicinities of Dęblin: A - Новая Топографическая Карта Западной России, 1:84,000, „XXV-11”, 1908; B - Spezialkarte der Österreichisch-Ungarischen Monarchie, 1:75,000, „Zone: B, Kol. XXVI-Iwangorod”, 1914; C - Karte des Westlichen Russlands, 1:100,000, „K35 Iwangorod”, 1915 
hydrography relief, and borders. Within each layer all categories were compared and in the process of matching and unifying the categories semantic analogies method was used. These categories in which case the matching proved to be impossible were mentioned separately at the end of the tables.

All the analysed maps depict both concentrated settlement as well as scattered housing (tab. 1). The Russian map, however, mentions the additional symbol for farm, which can refer to outbuilding on Spezialkarte and khutor (small isolated housing unit). As far as the range of build-up areas on the map is concerned, on the sheets covering Pultusk, Dęblin and Brest it is similar, however in the area of Pinsk there are significant differences between the maps. While the German and Russian map show similar area of Pinsk, on the Austrian one the city is significantly smaller (fig. 1).

What seems also interesting is the manner of depicting Brest Fortress. The fortifications had been built since the half of 19th century, when the citadel and three fortifications were erected at the outlet of River Muchawiec to River Bug. Subsequently, in the years 1878-1888

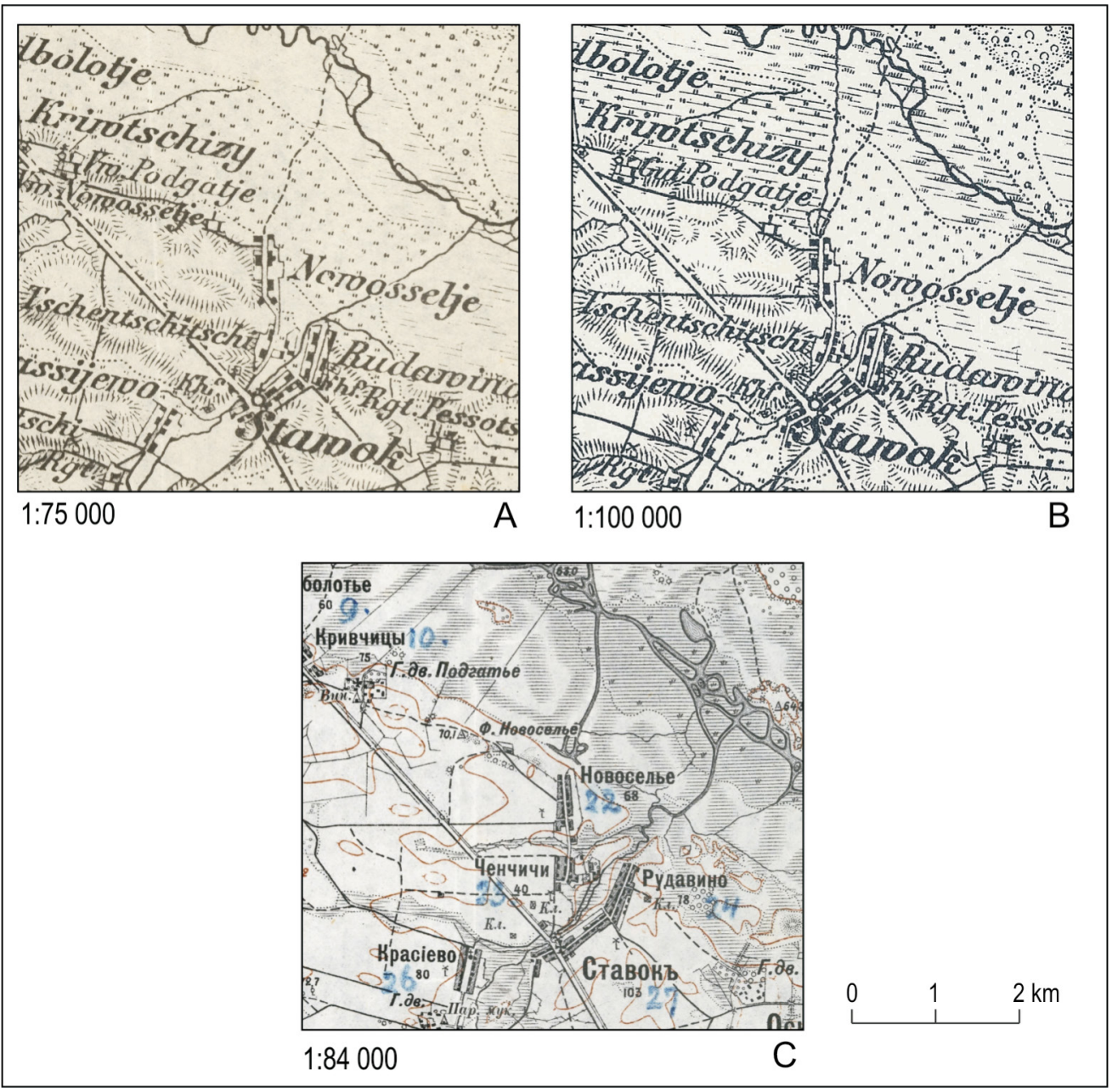

Fig. 3. Vicinities of Pinsk: A - Spezialkarte der Österreichisch-Ungarischen Monarchie, 1:75,000, „Zone: D, Kol. XXXIV”, 1914; B - Karte des Westlichen Russlands, 1:100,000, „S33“, 1915; C - Новая Топографрическая Карта Западной России, 1:84,000, „XXIII-20”, 1915 
Tab. 2. Transport network

\begin{tabular}{|c|c|c|}
\hline $1: 84,000$ & $1: 75,000$ & $1: 100,000$ \\
\hline \multicolumn{3}{|c|}{ Railways } \\
\hline Double-track railroad & Double-track railroad & Double-track railroad \\
\hline Single-track railroad & Single-track railroad & Single-track railroad \\
\hline $\begin{array}{l}\text { Single-track railroad with } \\
\text { substructure for a second track }\end{array}$ & $\begin{array}{l}\text { Single-track railroad with } \\
\text { substructure for a second track }\end{array}$ & $\begin{array}{l}\text { Single-track railroad with } \\
\text { substructure for a second track }\end{array}$ \\
\hline \multirow[t]{2}{*}{ Narrow-gauge railway } & $\begin{array}{l}\text { Narrow-gauge railroad } \\
\text { Light railway, tram }\end{array}$ & Industrial or street railways \\
\hline & Railway station & Railway station \\
\hline Halt & Halt & Halt \\
\hline \multirow[t]{4}{*}{ Railroad under construction } & Railroad under construction & \\
\hline & Cableway & \\
\hline & Lineman & \\
\hline & Tram stop & \\
\hline \multicolumn{3}{|c|}{ Roads } \\
\hline I class road & State road & State road \\
\hline II class road & District road & District road \\
\hline Post road in good condition & $\begin{array}{l}\text { Preserved gravel road } \\
\text { Good gravel road }\end{array}$ & Post road \\
\hline Post road in bad condition & Unpreserved gravel road & \\
\hline Rural wide road with ditches & & Local road with ditches \\
\hline Rural wide road without ditches & & Local road without ditches \\
\hline Industrial road & Road for wagons (rural or forest road) & Rural or forest road \\
\hline Rural road & Horse trail & \\
\hline Footpath & Footpath & Footpath \\
\hline Winter road & & Winter road \\
\hline Causeway and fascine road & Indistinct footpath & \\
\hline \multirow[t]{3}{*}{ Forest road } & The road has not been used & \\
\hline & Traces capable of crossing the road & \\
\hline & Road for the sleigh & \\
\hline \multicolumn{3}{|c|}{ Crossings } \\
\hline \multirow[t]{2}{*}{ Bridge on rafts } & Wooden railway bridge & \multirow[t]{2}{*}{ Bridge on rafts } \\
\hline & Wooden road bridge & \\
\hline Bridge on rafts & Bridge on rafts & Bridge on rafts \\
\hline \multirow[t]{2}{*}{ Iron bridge } & Iron railway bridge & \multirow[t]{2}{*}{ Iron bridge } \\
\hline & Iron road bridge & \\
\hline Ford for horses & Ford for horses & \\
\hline Ford for pedestrians & Ford for men & \\
\hline Tunnel & Tunnel & \\
\hline
\end{tabular}


The comparison of the scope of the content and classification methods on topographical maps...

\begin{tabular}{|c|c|c|}
\hline $1: 84,000$ & $1: 75,000$ & $1: 100,000$ \\
\hline \multirow[t]{2}{*}{ Floating bridge } & Stone railway bridge & \multirow[t]{2}{*}{ Stone bridge } \\
\hline & Stone road bridge & \\
\hline & Bridge without sleepers & \\
\hline & Stone culvert & \\
\hline & Wood culvert & \\
\hline & Footbridge for horses & \\
\hline & Footbridge people & \\
\hline & Carriage for railways & \\
\hline & Temporary bridge & \\
\hline & Steamboat transportation & \\
\hline & Ferry for cars & \\
\hline & Ferry for people & \\
\hline & Ferry for horses & \\
\hline & Ford for cars & \\
\hline & Bridge without sleepers & \\
\hline
\end{tabular}

the inner circle with its nine fortresses was built. At the beginning of 20th century a decision to extend the defence of the fortress was made. It was conducted by adding more than ten forts in the range of $40 \mathrm{~km}$ (S. Łagowski 2005). On the Central Powers maps the situation from the beginning of 20th century is illustrated namely the citadel with two rings of fortifications, while on the Russian map in this place there is only a church and cemetery sign (fig. 6). What is more, the fortress appears on even older and less detailed map at the scale 1:126,000 from the year 1870 (Военно-топографрическая карта европейской России, sheet: „Riad: XVIII, List: 2”).

What also might draw one's attention are the names of the settlements, as the manner of their depiction seems poor on the Russian maps (only three categories) and very complex on the other counterparts. There is no content reclassification: the legend for the Austrian is one and the same for all map sheets (irrespective of the source materials). On the other hand while analysing the names on the German map drawing any conclusion seems risky due to the lack of source foundations. There are no explanations in the legend attached to particular map sheet. The fonts on the analysed map sheet covering the surroundings of Dęblin suggest that the classification was taken from the Russian map. However there are some significant differences between the names: Ryki (larger village), Moschtschanka [Moszczanka] (village) and demesne [Vorwerk] Ryki (farm) (fig. 2)

What is more, the names on Austrian and German maps was transcribed in different manners. On KdWR it is adjusted to German pronunciation, while on Spezialkarte to Polish one, e.g. "Moschtschanka" (KdWR) i "Moszczanka" (Spezialkarte), "Trshjanka" (KdWR) i "Trzcianka" (Spezialkarte) on the Dęblin sheet (fig. 2). It can stand in opposition to the findings described above, as Austrian map was an important source of data for the German one (B. Krassowski 1973). Why then the transcription differs? In the Austrian topographical service there were two Polish cartographers who might have been responsible for this "Polish way of pronunciation" - Gustaw Zygadłowicz and Paweł Schifman. However it may not necessarily be the case that they worked in fact with Spezialkarte (B. Olszewicz 1921).

The issue of Russian names transcription still remains unresolved: on the Pinsk sheets the names are transcribed consistently on both Central Powers maps, as well as on Russian one. Representing the relief by hachures and poor situation content prove that the source material might have been Reymann map (fig. 3) 


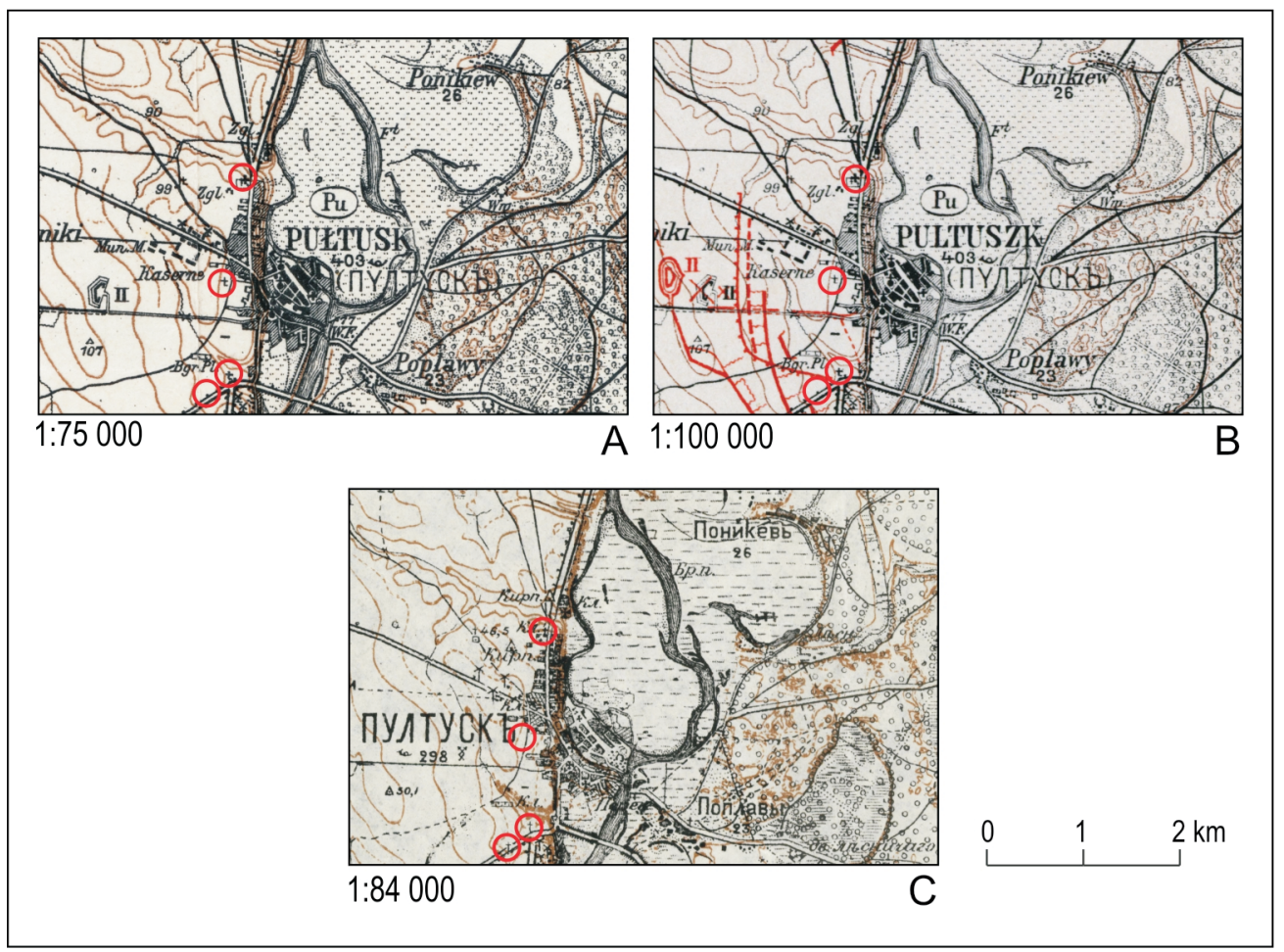

Fig. 4. Vicinities of Pułtusk, wayside crosses are marked with red circles: A - Spezialkarte der Österreichisch-Ungarischen Monarchie, 1:75,000, „2966”, 1916; B - Karte des Westlichen Russlands, 1:100,000, „H31 Pultusk“, 1915; C - Новая Топографрическая Карта Западной России, 1:84,000, „XXI-19”, 1915

Pinsk sheets seem to be a similar case. In this case, in turn Austrian map is a reprinted and enlarged German map. Even the names and topographical content, as well as the relief remains the same. All the observations above instantiate the inconsistencies both in terms of the form as well as content of the map, what may have resulted from different source materials.

The transport network can be divided into three subgroups: railroads, roads and passages, i.e. bridges, passages, fords, and tunnels (tab. 2). In the railway layer nearly all the classes from the Russian map were copied to the other two, except for the class "railroad under construction" which lacks on the German map. There is also a wider range of classes on the Austrian map. Problematic seems the category "industrial or street railway" found on KdWR ("Industrie- oder Strassenbahn"). In the symbology key by S. Gąsiewicz (1930) and J. Le- wakowski (1920) the category is represented by "narrow-gauge railway", while in symbol classification by WIG (1925) as "light railway, tram".

We encounter the same situation in the case of the passages, which were present on the Russian map, and consequently, were copied to the other ones. However, there was an array of additional categories included in Spezialkarte. As an example of inconsistencies, however, can serve a "stone bridge", which was exemplified on both maps of Central Powers, while it is absent from the Russian one.

What appears more complicated is the case of the road layer. The approach to this category of content on Austrian map is entirely different than on the Russian one: there is, for example, no information whatever concerning the ditches or winter road (there is, though, a road for the sleigh). More coherent seems to be Russian classification on the German sheet. It involves 


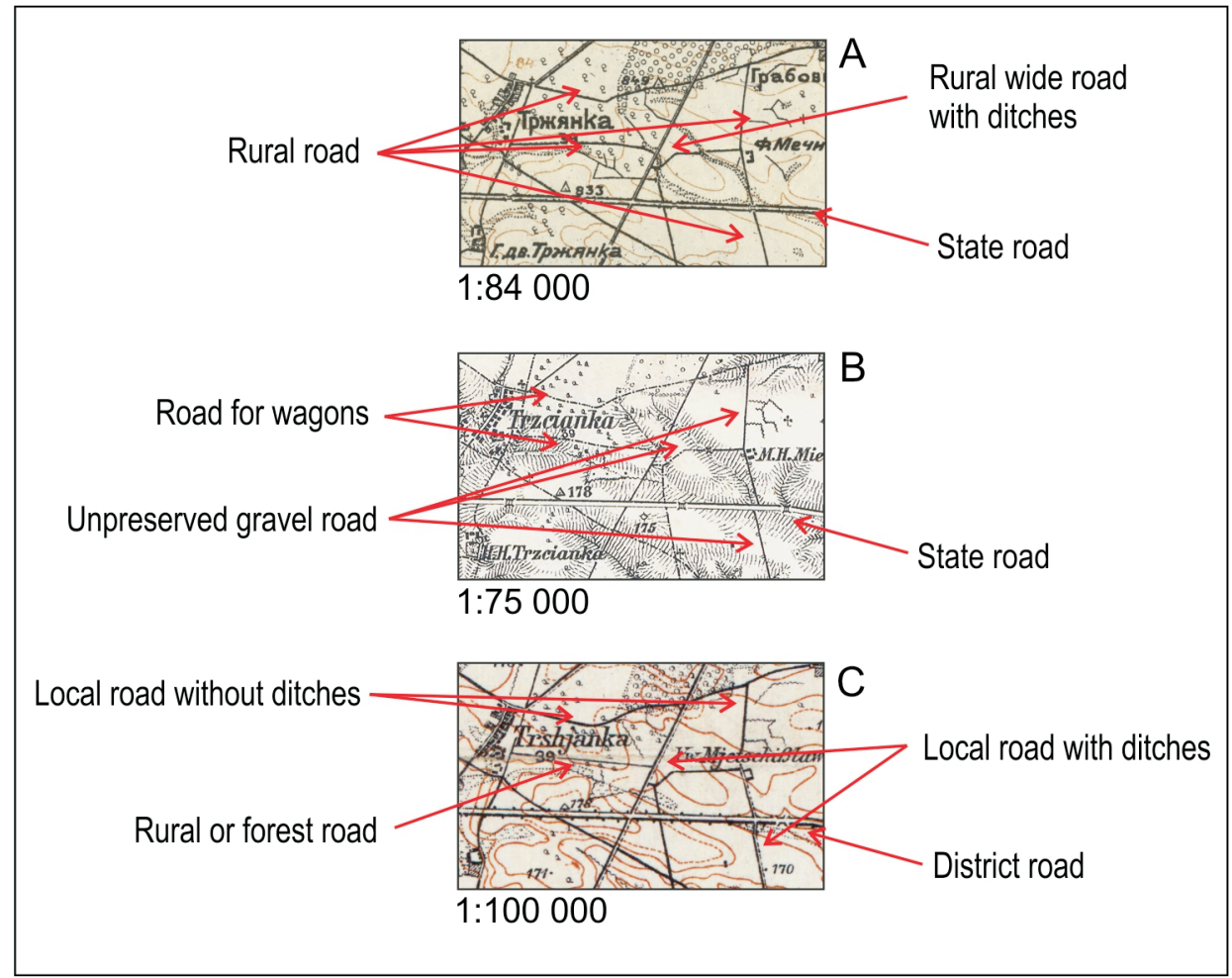

Fig. 5. Inconsistencies in roads classification methods in Dęblin vicinities: A - Новая Топографрическая Карта Западной России, 1:84,000, „XXV-11”, 1908; B - Spezialkarte der Österreichisch-Ungarischen Monarchie, 1:75,000, „Zone: B, Kol. XXVI-Iwangorod”, 1914; C - Karte des Westlichen Russlands, 1:100,000, „K35 Iwangorod”, 1915

the "post road", "local road with (or without) ditches", "winter road", "rural road", while it lacks "farm road" and "fascine road".

The situation complicates even more when we consider each separate map sheets. "Il class road" from two-verst map is illustrated as "state road" on Austrian map and as "district road" on $K d W R$. Numerous "rural roads" in turn, from the Russian sheets become "roads for wagons" or "unpreserved gravel roads" (Spezialkarte) or "local roads without ditches", "local roads with ditches", or "rural and forest roads" (KdWR). Stretching along the meridians "local road with ditches" (two-verst map) is "unpreserved gravel road" on the Austrian map and "local road with ditches" on German one (fig. 5). Sometimes, the analysed maps differ in terms of road network density. On the Brest sheets, North of the city the German and Austrian maps present the higher-category roads, which are missing from the Russian one (fig. 6).

Even such a small section of a map shows the lack of connections in classification and presentation methods between maps, especially while taking into consideration the "lower" categories. This indicates the haste accompanying the works on the Austrian and German maps, which were supposed to serve as a tool in the invasion on Russia in 1914. However, the credible and detailed information on road class, especially in the context of heavy gear transport can decide about the success of military actions.

In the layers concerning the sacral objects and outbuildings a huge disproportion can be observed in the aspect of scope of map content on Austrian and remaining two maps (tab. 3). There are also inconsistencies in the approach 


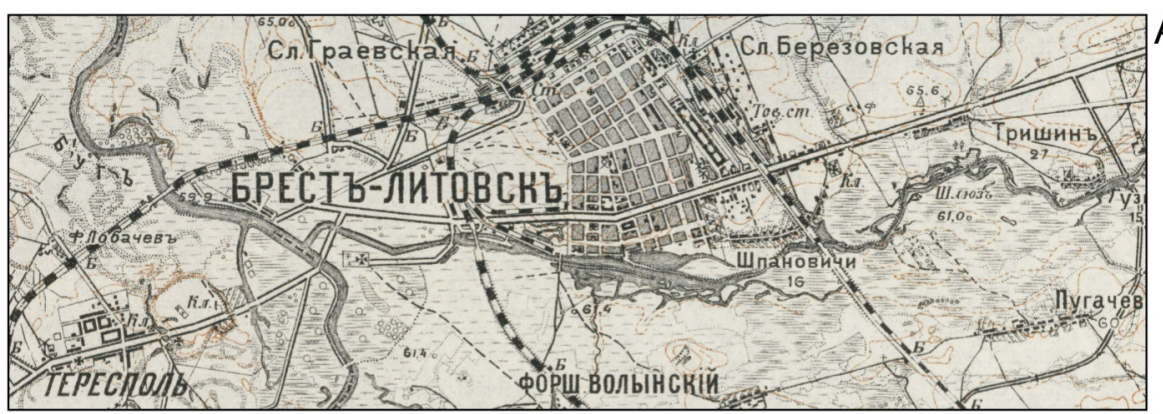

1:84 000

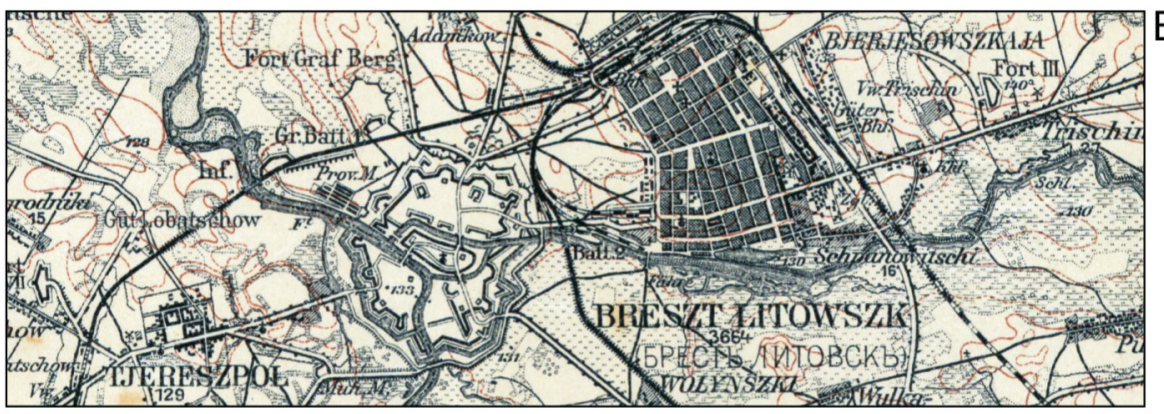

$1: 75000$

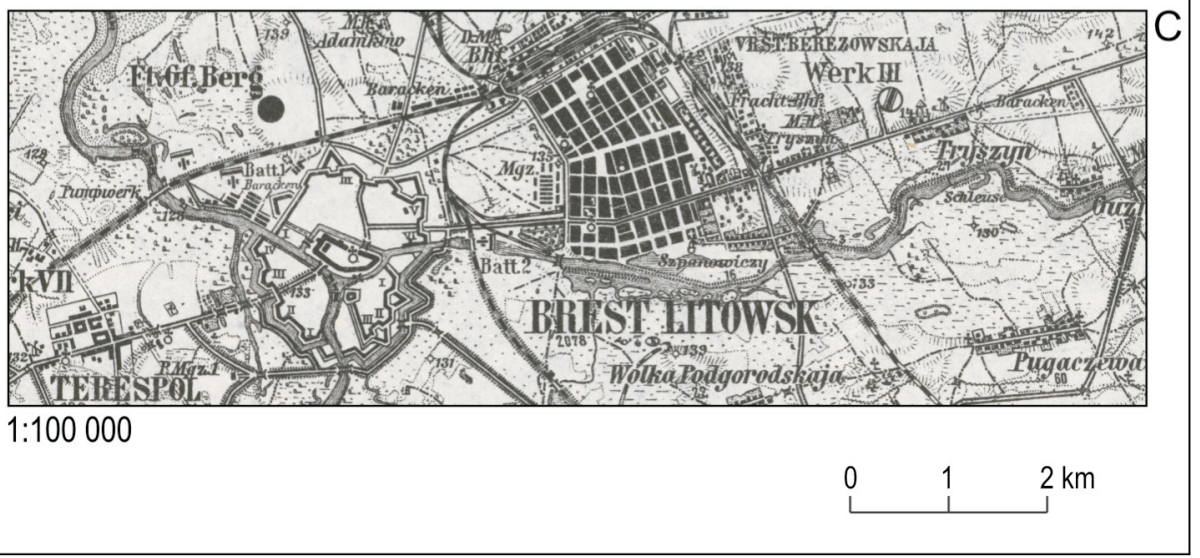

Fig. 6. Vicinities of Brest: A - Новая Топографическая Карта Западной России, 1:84,000, „XXIII-15”, 1915; B - Spezialkarte der Österreichisch-Ungarischen Monarchie, 1:75,000, „Zone: D, Kol: XXIX;

Brest-Litowsk”, 1911; C - Karte des Westlichen Russlands, 1:100,000, „N33 Bresst-Litowssk”, 1914

to the classification. The Russian map distinguishes two types of churches - brick and wooden, while its Austrian counterpart divided the objects according to the number of tower (no tower, one and two) and on German one there is no distinction at all.
Moreover, the German map does not include freestanding wayside crosses in the legend. On the map sheet covering the area of Dęblin there is nothing in the places, where on two-verst map and Spezalkarte there is a cross. On the one with Pultusk, however, on German 
Tab. 3. Sacral buildings, facilities and other buildings

\begin{tabular}{|c|c|c|}
\hline $1: 84,000$ & $1: 75,000$ & $1: 100,000$ \\
\hline \multicolumn{3}{|c|}{ Sacral buildings } \\
\hline \multirow{2}{*}{ Stone church } & Church with two or more towers & \multirow{2}{*}{ Church } \\
\hline & Church without or with one tower & \\
\hline \multirow{2}{*}{ Synagogue } & $\begin{array}{l}\text { Synagogue with two or more } \\
\text { towers }\end{array}$ & \multirow{2}{*}{ Synagogue } \\
\hline & $\begin{array}{l}\begin{array}{l}\text { Synagogue without or with one } \\
\text { tower }\end{array} \\
\end{array}$ & \\
\hline \multirow{2}{*}{ Mosque } & Mosque without or with one tower & \multirow{2}{*}{ Mosque } \\
\hline & Mosque with two or more towers & \\
\hline Chapel & Chapel & Chapel \\
\hline Christian cemetery & Cemetery & Christian cemetery \\
\hline Christian cemetery & & Christian cemetery \\
\hline Religious figure & Religious figure & Religious figure \\
\hline Cross & Cross & \\
\hline \multirow[t]{3}{*}{ Wooden church } & Large monastery & \\
\hline & Small monastery & \\
\hline & Old grave & \\
\hline \multicolumn{3}{|c|}{ Facilities } \\
\hline Mansion & Mansion & Mansion \\
\hline Demesne & Demesne & Demesne \\
\hline \multirow[t]{2}{*}{ Brickyard } & Steam brickyard & Brickyard \\
\hline & Brickyard & \\
\hline Inn & Inn & Inn \\
\hline Apiary & & Apiary \\
\hline \multirow[t]{2}{*}{ Windmill } & Windmill & Windmill \\
\hline & Wind turbine & \\
\hline \multirow{3}{*}{ Mill } & Artificial mill & \multirow{3}{*}{ Water Mill } \\
\hline & Water Mill & \\
\hline & Mill on the boats & \\
\hline Sawmill & Sawmill & Sawmill \\
\hline \multirow{2}{*}{ Mine } & \multirow{2}{*}{ Mine } & Mine \\
\hline & & Closed mine \\
\hline \multirow[t]{13}{*}{ Factory } & Factory & \\
\hline & Wood tar distillation & Lime kiln or wood tar distillation \\
\hline & Quarry & Quarry \\
\hline & Power station & \\
\hline & Blast furnace & \\
\hline & Smith & \\
\hline & Oil source & \\
\hline & Oil tank & \\
\hline & Saw & \\
\hline & Mortar & \\
\hline & Little mortar & \\
\hline & Lime container & \\
\hline & Hotel & \\
\hline
\end{tabular}




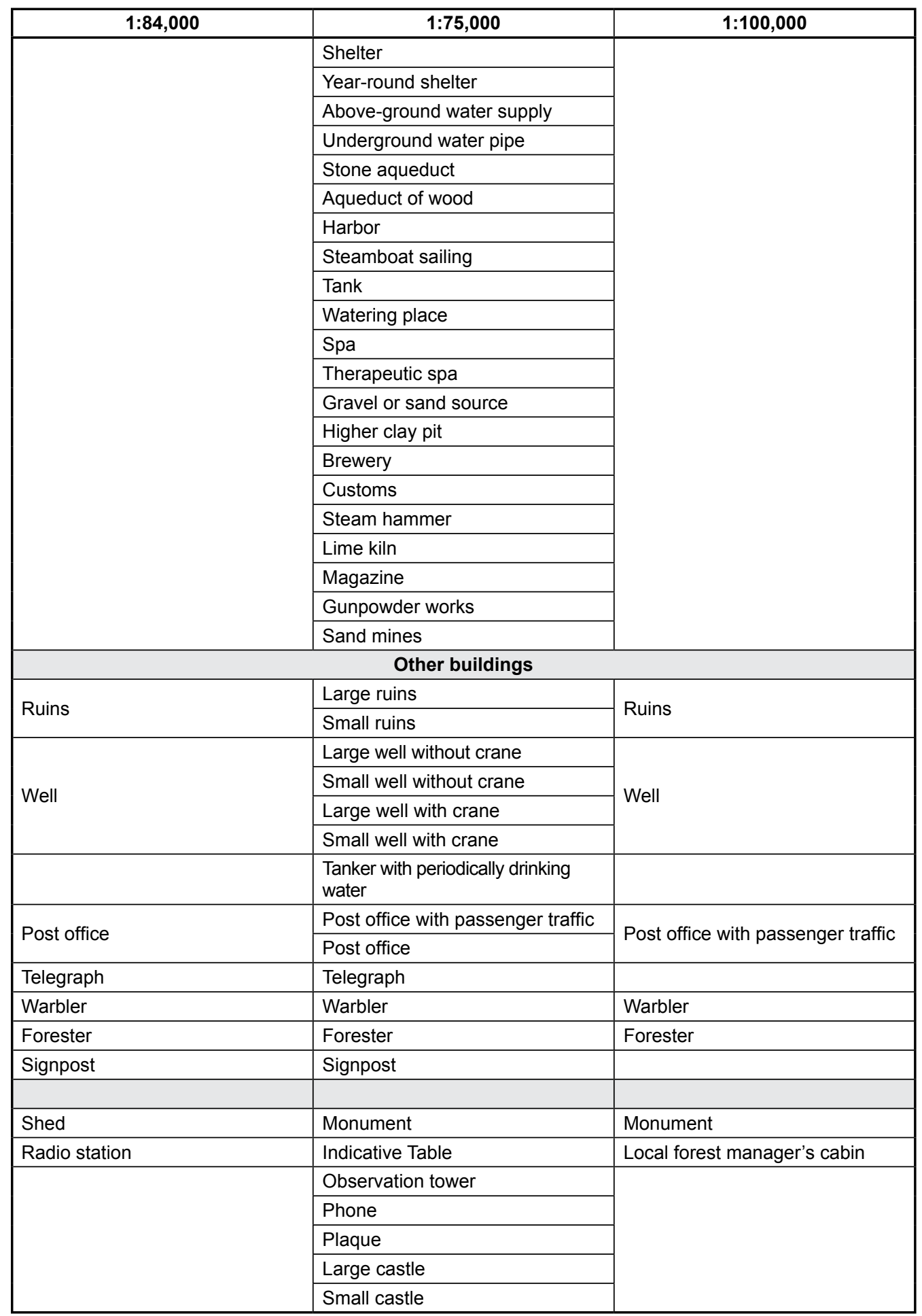


and Austrian map the wayside crosses (not all of them) are present, where on the Russian one, being the source, they are missing. Those places are shown on the figure with red circle (fig. 4).

All outbuildings on the Russian map have their counterparts on the other two, however "apiary" can be found only on the German map, while "factory" on the Austrian. The categories on the Austrian maps tend to be more detailed, what is clearly visible on the example of the mills (three categories). On German map the mines are divided into working and abandoned, what leads to the question of the source of such information, as neither Russian nor Austrian map show such division. Two classes - "lime kiln" and "wood tar distillation", as well as a "quarry" are only on the Spezialkarte and $K d W R$ legends.

Among the elements classified as others there are two categories on the Russian map which have no counterparts on the other two

Tab. 4. Land use

\begin{tabular}{|c|c|c|}
\hline $1: 84,000$ & $1: 75,000$ & $1: 100,000$ \\
\hline Forest & \multirow{3}{*}{ Forest } & Forest \\
\hline Forests and wet meadows & & Swamp forest \\
\hline Burned forest & & Rare forest in the meadow \\
\hline Bushes & Bushes and thickets & Bushes and thickets \\
\hline Meadow & Meadow, Pasture & Meadow, Pasture \\
\hline Fruit and vegetable gardens & Fruit and vegetable gardens & Fruit and vegetable gardens \\
\hline Sands & & Sands \\
\hline \multirow{4}{*}{ Vineyard, cultivation of hops } & German culture vineyard & \multirow{3}{*}{ Vineyard } \\
\hline & Vineyard on patches & \\
\hline & Italian culture vineyard & \\
\hline & Plantation hops & \\
\hline Tree visible from afar & Tree visible from afar & Tree visible from afar \\
\hline Garden & & Vegetable gardens \\
\hline Fields & Fields & \\
\hline Park & Park & Park \\
\hline \multirow{2}{*}{ Swamp } & Marshy ground & \multirow{2}{*}{ Swamp } \\
\hline & Swamp & \\
\hline Moor & Moor & \\
\hline \multirow[t]{2}{*}{ Impassable swamp or moor } & \multirow[t]{2}{*}{ Swamp with moor } & Impassable swamp \\
\hline & & Passable swamp \\
\hline Rushes in the swamp & $\begin{array}{l}\text { Rushes in the swamp with di- } \\
\text { stinct limit }\end{array}$ & \\
\hline \multirow[t]{8}{*}{ Felling } & Single trees & \\
\hline & Trees in groups & \\
\hline & Trees in the ranks & \\
\hline & Rice field & \\
\hline & Permanent wetlands & \\
\hline & Periodic wetlands & \\
\hline & Swamp-drying places & \\
\hline & Reed thickets & \\
\hline
\end{tabular}


maps, namely: a "shed" and a "radiostation", and similarly on the Austrian and German maps there are classes missing from the two-verst one, namely: "monument" (Spezialkarte and $K d W R$ ), local forest manager's cabin" (KdWR), or "telephone" (Spezialkarte).

Significant differences can be also found in the land use and land cover (tab. 4). The two- omitted on $K d W R$. It can be explained by the fact that on the analysed area there were no waterfalls.

Particularly surprising seems the classification of ditches, which on Russian map can be either narrow or wide, on German wet and dry and Austrian natural or artificial. There is also an array of important categories on Spezial-

Tab. 5. Hydrography

\begin{tabular}{|c|c|c|}
\hline $1: 84,000$ & $1: 75,000$ & $1: 100,000$ \\
\hline River & River & River \\
\hline Waterfall & Waterfall & \\
\hline Lake & Lake & Lake \\
\hline \multirow{2}{*}{ Source } & Abundant source & \\
\hline & Less abundant source & \\
\hline Narrow trench & Dry trench (natural) & Wet trench \\
\hline \multirow[t]{6}{*}{ Wide trench } & Dry trench (artificial) & Dry trench \\
\hline & Stream & Stream \\
\hline & Channel & Channel with the lock \\
\hline & Water disappearing into the ground & Wet ground \\
\hline & Ponds & Sluice \\
\hline & $\begin{array}{l}\text { Standing water overgrown with } \\
\text { reeds }\end{array}$ & Weir \\
\hline
\end{tabular}

-verst categories "forests and wet meadows" and "felling" have no respective categories on the other two maps though those landscape components seem to be fairly important from the military perspective. What is more, German map only has the distinction between swamp, which is "passable" and "impassable". The question of such division arises then.

On the sheets elaborated by Central Powers the range of particular classes are illustrated in a similar way, though in those cases where Reymann's map served as a primary data source, there are quite significant differences, especially in the context of swamps (fig. 3).

Hydrography has a minor place in the Russian map legend in comparison to the German and Austrian one (tab. 5). There are also noticeable inconsistencies in the content, starting from the "waterfall", which was marked on twoverst map legend and Spezialkarte, but was karte and $K d W R$, which have no counterparts on two-verst map, such as "channel", "sluice" and "weir". It is difficult to provide credible reason for such inconsistencies in the scope of content of maps being a source for one another, even taking into consideration short time of elaboration.

The relief on two-verst map is illustrated with contour lines in fathoms - every two fathom $(4.26 \mathrm{~m})-\mathrm{a}$ full line, every fathom $(2.13 \mathrm{~m})-$ a dashed line with additional height-points. Austrian cartographers, in order to maintain the uniformity of the entre Spezialkarte series decided to supplement the contour lines with hachure. The contour lines, therefore, are less dense - every $50 \mathrm{~m}$ - a dashed line, and every $100 \mathrm{~m}$ - a full line.

On those sheets of $K d W R$, which source material was two-verst map nearly all the stretch of the contour line was copied (J. Kreutzinger 
Tab. 6. Relief

\begin{tabular}{|c|c|c|}
\hline $1: 84,000$ & $1: 75,000$ & $1: 100,000$ \\
\hline Contour lines (in fathom) & Contour lines (in meters) & Contour lines (in meters) \\
\hline Hachures & $\begin{array}{c}\text { Hachures (where the Reymann } \\
\text { map was source material) }\end{array}$ \\
\hline Elevation points & Elevation points & Elevation points \\
\hline
\end{tabular}

Tab. 7. Borders

\begin{tabular}{|c|c|c|}
\hline $1: 84,000$ & $1: 75,000$ & $1: 100,000$ \\
\hline State border & State border & State border \\
\hline Province border & Country border & Province border \\
\hline District border & District border & District border \\
\hline
\end{tabular}

1928). Sometimes they were supplemented with additional dashed contour lines, despite the change of the scale from $1: 84,000$ to $1: 100,000$ and the lack of actual verification in the real life.

Where the primary source was the Reymann map (Pinsk area sheets) on the maps of Central Powers there is a hachure (no contours in case of Spezialkarte), which illustrates the direction and land slope impossible to infer from the two-verst map (fig. 3).

The borders is the only thematic layer similar on all three map series (tab. 7). The only difference is the label "country border" in place of "province border" on the Russian and German ones.

\section{Conclusions}

On the basis of the analysis above we can indicate a number of significant differences in terms of scope and classification methods on the map series in question. This allows to sustain the hypothesis, that despite similarity of scale $(1: 75,000,1: 84,0001: 100,000)$ and source data those maps approach the issue of content classification differently. Those differences are observable in all thematic layers, ranging from settlement, which are illustrated on the Russian map in a schematic and on others in more detailed manner, through the transport network (especially roads), to the land use and hydrography where the elements are classified according to completely disparate criterion.
It is also common to omit on the Central Power maps certain content present on the Russian map, e.g. "fascine roads", "wooden churches" and "radiostations".

Inconsistencies in classification to large extent concern the cultural landscape as it is more complicated to model it. However such classes as "woods" and "swamps", which are present on all the maps in the general form, prove to reveal different subclasses while focusing on particular detail (e.g. "fallings", "passable swamps", "wetlands") are not included in all maps.

Such discrepancies cannot be explained by military character of the works. It is clear that the Central Powers maps are not necessarily a copy of the Russian one. Even in case of the maps based on the one at the scale 1:84,000 (what is indicated by nearly identical contour lines on both Russian and German maps), there are deliberate editing interventions and omission, such as the lack of wayside crosses on the German map where they were present on the Russian counterpart and at the same time some crosses can be found in places where Russian map lacks such symbol (the symbol however is missing from the German map legend whatsoever). If the priority was the time of map sheet elaboration, there would be no such corrections. The changes were not restricted to simplification, what is proven by the case of Brest Fortress on the Central Powers maps.

It is worth mentioning that due to different approach to topographical content such maps 
can, despite their shortcomings, be an important asset and source of data about a particular historical moment, especially if we consider the possibilities of GIS tools. The geospatial databases require a coherent conceptual model for the attribute data - a model that can be elaborated on the basis of all three map series,

\section{References}

Archiwum Map Wojskowego Instytutu Geograficznego, 2015. http://www.mapywig.org/ access: 2015.03.19.

Cartomatic, 2015, Mapy z przeszłością. Maps with the past. http://hgis.cartomatic.pl/ dostęp: 2015.02.24.

Faluszczak F.P., 2011, Kartografia Galicji Wschodniej w latach 1772-1914. Rzeszów: Wydawnictwo Uniwersytetu Rzeszowskiego.

Gąsiewicz S., 1930, Znaki topograficzne map. Warszawa: Główna Księgarnia Wojskowa.

Gregory I.N., Healey R.G., 2007, Historical GIS: structuring, mapping and analysing geographies of the past. „Progress in Human Geography” Vol. 31, no. 5, pp. 638-653.

Grygorenko W., 1981, Założenia metrologiczne map XVII i XVIII wieku. „Przegląd Geodezyjny” R. 53, 1981, nr 9-10, pp. 286-289.

Konias A., 2010, Kartografia topograficzna państwa i zaboru pruskiego od II połowy XVIII wieku do połowy XX wieku. Słupsk: Wydawnictwo Naukowe Akademii Pomorskiej.

Konopska B., Ostrowski J., Pasławski J., Weszpiński P.E., eds, 2012, Dawne mapy jako źródła historyczne. „Biblioteka Polskiego Przeglądu Kartograficznego", Warszawa.

Krassowski B., 1973, Polska kartografia wojskowa 1918-1945. Warszawa: Wydawnictwo MON.

Kreutzinger J., 1928, Topografja. Pomiar i zdjęcie kraju, kartografja $i$ wojskowe znaczenie terenu. Warszawa: Wojskowy Instytut Geograficzny.

Kuna J., 2014, Zmiany znaków na XX-wiecznych mapach topograficznych $w$ skali 1:100 000. „Polski Przegl. Kartogr.” T. 46, 2014, nr 1, pp. 47-61.

Lange K., 2013, Kalibracja dawnych map zasięgu lodów morskich w Arktyce z zastosowaniem systemów informacji geograficznej. „Polski Przegl. Kartogr.” T. 45, nr 4, pp. 344-351.

Lewakowski J., 1920, Klucz znaków przyjęty dla map austriackich, rosyjskich i pruskich. Warszawa, Kraków: Księgarnia J. Czarneckiego.

Lewakowski J., 1921, Terenoznawstwo i kartografia wojskowa. Warszawa, Kraków: Księgarnia J. Czarneckiego. then, seems to be an interesting challenge. The GIS tools can be useful in the further research on those maps, as due to elaboration of a database involving all the objects and their locations with their categories we can point particular instances as well as identify general differences in the map elaboration methods.

Libiński H., 1912, Jak czytać austriackie mapy wojskowe i orientować się za ich pomocą $w$ terenie? Kraków: Księgarnia Gebethner i Spółka.

Lorek D., 2012, Informacja topograficzna na Urmesstischblätter a objaśnienia w legendzie, in: Dawne mapy jako źródła historyczne, „Biblioteka Polskiego Przeglądu Kartograficznego", Warszawa, pp. 55-61.

Łagowski S., 2005, Szlakiem twierdz i ufortyfikowanych przedmości. Pruszków: Oficyna Wydawnicza „Ajaks”.

Nieścioruk K., 2007, Analiza i ocena XVIII-wiecznego planu Lublina jako przykład kompleksowych badań dawnych materiałów kartograficznych. „Polski Przegl. Kartogr.” T. 39, nr 2, pp. 146-158.

Olszewicz B., 1921, Polska kartografia wojskowa. Warszawa: Główna Księgarnia Wojskowa.

Panecki T., 2014a, Creating a common symbol classification for a new historical geoportal of Poland. „Miscellanea Geographica” vol. 18, no. 4, pp. 34-40.

Panecki T., 2014, Problemy kalibracji mapy szczegółowej Polski w skali 1:25 000 Wojskowego Instytutu Geograficznego w Warszawie. „Polski Przegl. Kartogr.” T. 46, nr 2, pp. 162-172.

Pietkiewicz S., 1995, Analiza dokładności niektórych map z XVII, XVIII i XIX wieku, obejmujących Polskę $w$ dawnych granicach. „Prace i Studia Geograficzne” T. 17, pp. 103-109.

Plit J., Nita J. (red.), 2012, Źródła kartograficzne w badaniach krajobrazu kulturowego. „Prace Komisji Krajobrazu Kulturowego" T. 16. Sosnowiec: Komisja Krajobrazu Kulturowego Polskiego Towarzystwa Geograficznego.

Sobala A., 2012, Zastosowanie austriackich map katastralnych w badaniach użytkowania ziemi w połowie XIX wieku. „Polski Przegl. Kartogr.” T. 44, nr 4, pp. 324-333.

Szady B., 2008, Zastosowanie systemów informacji geograficznej w geografii historycznej. „Polski Przegl. Kartogr.” T. 40, 2008, nr 3, pp. 279-283.

WIG, 1925, Zestawienie znaków topograficznych map austriackich, niemieckich i rosyjskich. Warszawa: Wojskowy Instytut Geograficzny. 